\title{
"Testing the fruitfulness of the institutional environment for the development of innovative-entrepreneurial universities in Ukraine"
}

\begin{tabular}{|c|c|}
\hline \multirow{7}{*}{ AUTHORS } & Andriy Stavytskyy id https://orcid.org/0000-0002-5645-6758 \\
\hline & R http://www.researcherid.com/rid/C-9560-2016 \\
\hline & Oleksandr Dluhopolskyi iD https://orcid.org/0000-0002-2040-8762 \\
\hline & Ganna Kharlamova iD https://orcid.org/0000-0003-3614-712X \\
\hline & R http://www.researcherid.com/rid/D-2804-2016 \\
\hline & Anatolii Karpuk iD https://orcid.org/0000-0003-2920-8131 \\
\hline & Valeriy Osetskyi iD https://orcid.org/0000-0001-5104-1070 \\
\hline ARTICLE INFO & $\begin{array}{l}\text { Andriy Stavytskyy, Oleksandr Dluhopolskyi, Ganna Kharlamova, Anatolii Karpuk } \\
\text { and Valeriy Osetskyi (2019). Testing the fruitfulness of the institutional } \\
\text { environment for the development of innovative-entrepreneurial universities in } \\
\text { Ukraine. Problems and Perspectives in Management, 17(4), 274-288. } \\
\text { doi:10.21511/ppm.17(4).2019.23 }\end{array}$ \\
\hline DOI & http://dx.doi.org/10.21511/ppm.17(4).2019.23 \\
\hline RELEASED ON & Friday, 20 December 2019 \\
\hline RECEIVED ON & Thursday, 10 October 2019 \\
\hline \multirow[t]{2}{*}{ ACCEPTED ON } & Monday, 25 November 2019 \\
\hline & $(\mathrm{cc}) \overline{E Y}$ \\
\hline LICENSE & $\begin{array}{l}\text { This work is licensed under a Creative Commons Attribution } 4.0 \text { International } \\
\text { License }\end{array}$ \\
\hline JOURNAL & "Problems and Perspectives in Management" \\
\hline ISSN PRINT & $1727-7051$ \\
\hline ISSN ONLINE & $1810-5467$ \\
\hline PUBLISHER & LLC "Consulting Publishing Company "Business Perspectives" \\
\hline FOUNDER & LLC "Consulting Publishing Company "Business Perspectives" \\
\hline
\end{tabular}

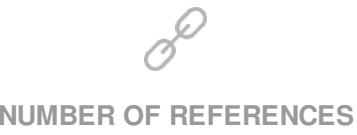

32
NUMBER OF FIGURES

5
NUMBER OF TABLES

(C) The author(s) 2022. This publication is an open access article. 


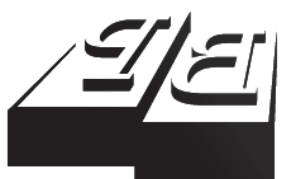

BUSINESS PERSPECTIVES

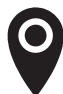

LLC "CPC "Business Perspectives" Hryhorii Skovoroda lane, 10, Sumy, 40022, Ukraine

www.businessperspectives.org

Received on: $10^{\text {th }}$ of October, 2019 Accepted on: $25^{\text {th }}$ of November, 2019

\section{(C) Andriy Stavytskyy,}

Oleksandr Dluhopolskyi, Ganna

Kharlamova, Anatolii Karpuk,

Valeriy Osetskyi, 2019

Andriy Stavytskyy, Ph.D., Associate Professor, Economic Cybernetics Department, Taras Shevchenko National University of Kyiv, Ukraine.

Oleksandr Dluhopolskyi, Doctor of Economics, Professor, Economics and Economic Theory Department, Ternopil National Economic University, Ukraine.

Ganna Kharlamova, Ph.D., Associate Professor, Economic Cybernetics Department, Taras Shevchenko National University of Kyiv, Ukraine.

Anatolii Karpuk, Doctor of Economics, Professor, National University of Life and Environmental Sciences of Ukraine, Ukraine.

Valeriy Osetskyi, Doctor of Economics, Professor, Economic Theory, Macro and Microeconomics Department, Taras Shevchenko National University of Kyiv, Ukraine.

\section{(ㄷ)(ㄱ)}

This is an Open Access article, distributed under the terms of the Creative Commons Attribution 4.0 International license, which permits unrestricted re-use, distribution, and reproduction in any medium, provided the original work is properly cited.
Andriy Stavytskyy (Ukraine), Oleksandr Dluhopolskyi (Ukraine),

Ganna Kharlamova (Ukraine), Anatolii Karpuk (Ukraine), Valeriy Osetskyi (Ukraine)

\begin{abstract}
Strengthening the integration of higher education, research, and innovation is a crucial requirement of time. The entrepreneurial university today is considered and analyzed as a promising model for their combination. The educational and scientific systems of many countries are faced with the task of converging all vertices of the "knowledge triangle." The problem of Ukrainian educational and scientific system is a necessity to implement the concept of formation of the innovation and entrepreneurial model of a modern university, which will enable the effective implementation of administrative reforms in this field. The article aims to analyze the impact of innovative environmental factors on the development of entrepreneurial universities in Ukraine, based on correlation and panel regression analysis. The method of quantitative analysis (panel regression) is used to formulate the key results of the article. The results show that the growth of government expenditures by $1 \%$ leads to an increase in the Global Innovation Index by 0.375 in 4 years. Also, every additional $1 \%$ of people working with new technologies increases the level of Global Innovation Index by 0.75 annually. Despite European trends, Ukrainian educational environment does not contribute to the development of innovation and entrepreneurial universities (the education expenditures are ineffective). The research provides a vector for understanding the implementation of the most effective strategies of promising innovation and investment development of education and science in Ukrainian universities, considering their existing potential and contemporary world trends of development.
\end{abstract}

\section{Keywords}

\section{JEL Classification}

higher education, universities, innovation, research and development, government expenditures, indexes

\section{INTRODUCTION}

The transformation of the world industrial economy into a knowledge-based economy or digital society (from Industry 1.0 to Industry 4.0) caused the global university education modernization. Recently, much attention has been paid in the scientific literature to the assessment of the innovative potential of various economic systems. The inadequacy of the traditional model of organization and functioning of the university to the global information society realities has become apparent for a significant part of practitioners and researchers of university management and economics.

The radical transformations are taking place in the sector of higher education of socially and economically developed countries. It is associated with the decisive importance of higher education institutions for innovative progress and economic growth and, as a result, the leading 
factor to the prosperity of states and citizens' well-being. The indicators of a change in the socio-economic functions of the university revealed in the simultaneous change in its scientific and educational missions. A fast-growing space of universities economic progress became more demanded during the last years. The new field of activity of the university includes development and transfer of technologies, commercialization of the academic science results and their presentation on the market, creation of new businesses, management of intellectual property to make a profit. The modern university accepts the goal of social and economic development.

The main historic landmark of the issue is that in the US after the adoption of the Bayh-Dole Act (BayhDole Act, 1980), the universities created more than 2 thousand companies (260 thousand jobs) during several years, which were engaged in the technology commercialization. At the same time, in Europe, the main role in creating public universities was assigned to the knowledge because they are at the intersection of innovation, research, and education (European Commission, 2003). The concept of excellence networks creation is grounded on the idea of integrating the scientific environment of universities at the global level into network structures that use the strengths of their members (Reichert \& Tauch, 2003). At the European meeting in Hampton Court (2005), the universities, along with research and development, were called the foundation of European competitiveness (European Commission, 2006). Thus, the University of Cambridge turned the Cambridgeshire county into an innovation cluster. Ten billion-dollar companies came out of it.

The problem is complicated by the increased competition between universities not only inside Ukraine but also worldwide. Unfortunately, the majority of Ukrainian universities cannot boast of the high quality of top management, which breaks any reforms in this sphere. It concerns the problem of implementing the concept of the innovation and entrepreneurial model for a modern university in Ukraine as well. However, the changes and adaptation to new university paradigm are impossible without deep understanding of innovation tendencies, modelling trends in it and considering macro-portrait of the modern innovative and entrepreneurial university and higher education in general. It should be mentioned that clear understanding of such trends, possible solutions, and models has to be obligatory for its successful implementation in practice. This statement sets a goal for the paper.

The structure of the paper is divided into six parts: discussing the theoretic background part, literature review part, purpose of the article and hypothesis part, part of testing the hypothesis and modelling main results, discussion part and finalizing with conclusions part.

\section{THEORETICAL}

\section{FRAMEWORK AND LITERA- TURE REVIEW}

Thus, the university, which is nowadays positioned as a corporate subject of the economy of knowledge, stuck the name University 3.0 or even University 4.0 (Figure 1). The evolution of universities goes through Education 1.0 (Guru-Shishya method of teaching), Education 2.0 (education enhancement with the teacher as the knowledge provider and the student as the passive recipient), to Education 3.0 (use of computers and internet in teaching and learning, which promoted the increased access and equity) and Education 4.0 (high-speed inter- net, mobile technology, social media platforms, etc.), facilitating personalized learning anytime anywhere and changing the role of teachers to facilitators and mentors (FICCI, 2017). It requires an analysis of the main tendencies of the innovation policy implementation in Ukraine, and the comprehension of the development prospects of modern universities revealed the contradiction between their capabilities and general approaches to the management organization in the scientific and educational process.

The results of previous studies on the subject developed the theoretical and applied problems in the management of knowledge and innovation economics, in particular, in the fields of science 
and higher education, human capital and intellectual property, technology transfer, and issues of increasing the competitiveness of Ukrainian universities in the context of the actualization and irreversibility of European integration processes, raising the importance of knowledge and strengthening national security. In particular, Osetskyi (2018), Osetskyi (2017) proposed the measures for the progress of academic entrepreneurship in Ukraine and a scheme for commercializing the results of scientific activity through such a form of academic separation as a spin-off company. The model "innovations - human capital - educational tendencies" and a complex of trainings on the development of soft skills and modern technologies of work with information are presented in the works of Ukrainian scientists (Koziuk, Dluhopolskyi, Hayda, \& Klapkiv, 2019; Kharlamova, Stavytskyy, \& Zarotiadis, 2018; Stavytskyy, 2018).
Higher education began to lose its elitist status in the middle of the XX century. The emergence of global economy, technological and digital expansion (Industry 4.0), the growth of knowledge production made higher education a mass service and directly responsible sector for the society's development. New challenges from the labor market also make influence on formal education process according to generation $\mathrm{Z}$ input (Stillman, 2018; Molchanova \& Dluhopolskyi, 2019). The mass nature of education is a huge factor that can be used effectively for the transfer and diffusion of entrepreneurship competencies and technological culture into society.

Scientific studies are gradually emerging, which analyze the modern university as a locomotive of economic development within the framework of the University 3.0 or 4.0 concept (education, research, commercialization of knowledge) (Lapteva

\begin{tabular}{|c|}
\hline Education 3.0 \\
\hline Learners as connectors, creators, \\
constructivists
\end{tabular}

- Student-centered approach

- The teacher is transformed into facilitator, adviser, learner, and practice guide

- The student is researching and self-learning

- Flip classroom method is applied

- More dialogue, technology is everywhere

- Social networks for connecting

- Access to experts

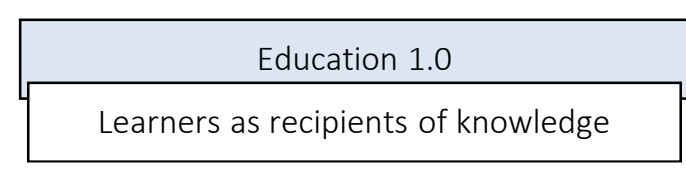

- Authoritarian

- The student is a passive recipient

- Teacher-centered system (the teacher gives knowledge as the absolute leader in the classroom)

- Technology is forbidden in the classroom

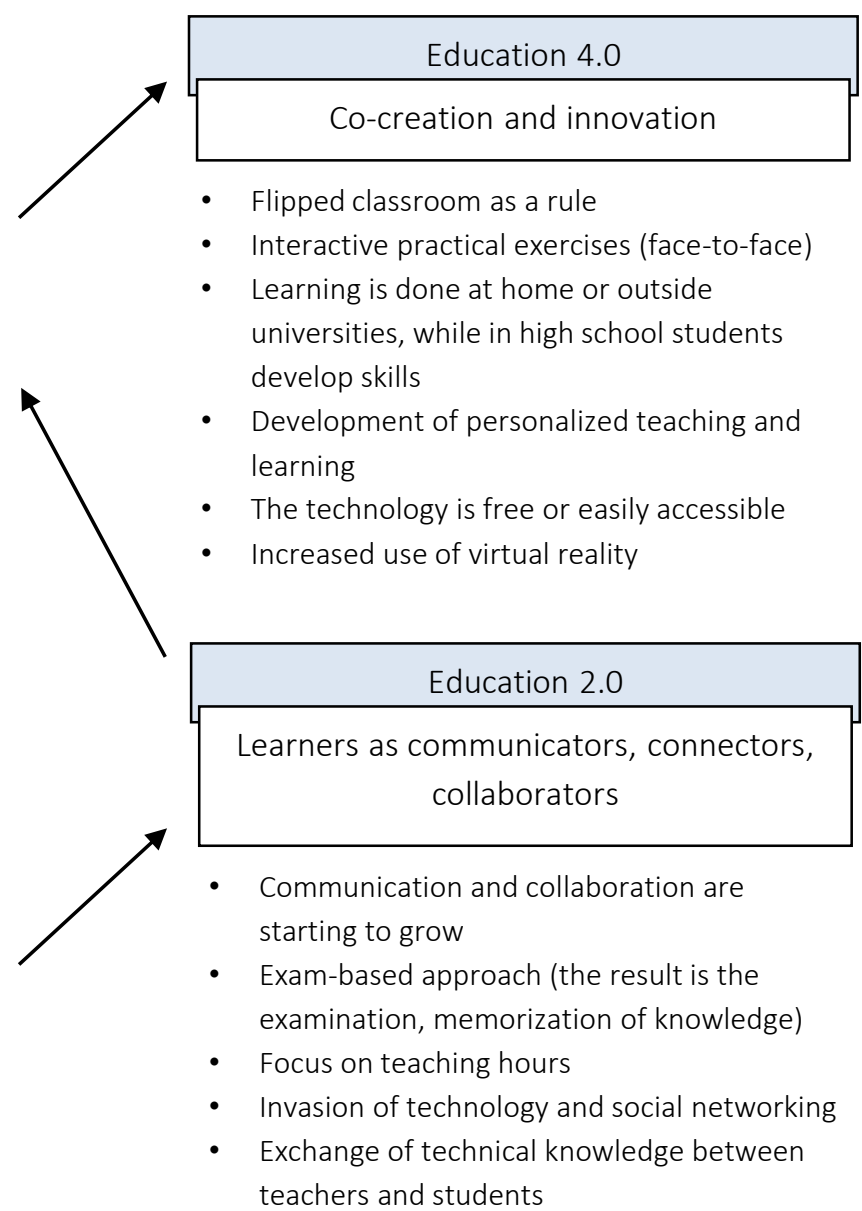

Figure 1. Education and universities development 
\& Efimov, 2016; Karpov, 2017; Kutsenko, 2010). Moreover, Stavytskyy (2018), Shevchenko (2019), Sotula and Denysenko (2019) showed that universities face numerous problems of transition to the European model of higher education, quality assurance system, which should be solved as soon as possible, otherwise, Ukrainian HEIs will lose completion to their neighbours.

It is shown how the University 3.0 or 4.0 becomes the basis of the global competitiveness of supranational associations, national economies, and local communities, and its entrepreneurial ecosystem forms new, fast-growing industries, promising technology markets, leading administrative and territorial spaces (Cole, 2010; Nour, 2016). University educational, scientific, and innovation complexes are currently the most important subjects of the innovation market in most countries (Eurostat, 2007). Relying on the scientific, technical, and personal potential of universities, it contributes to the effective development of small and medium-sized innovative enterprises. The results of such interaction can be seen in new industrial technologies, the growth of competitiveness of goods, the creation of new jobs (Lee \& Mason, 2010; Leutz, 2012; Rai, Brown, \& Ruwanpura, 2019).

The innovative potential of the University 3.0 and University 4.0 is considered by the researchers as the system indicator characterizing the level of effectiveness of the research and innovation complex in the implementation of the full innovation cycle. In this case, the educational component is taken into account only in terms of its impact on the production of high-tech products. The innovative potential of University 3.0 and University 4.0 reflects the ability of its innovative structures to prospective development at the expense of internal capabilities. The growth of the innovative potential of such university involves:

- effective development of human resources and research base (staff potential/strength);

- interaction with industrial enterprises (innovative potential);

- realization of competitive advantages (R\&D potential and production and technology potential); improvement of the organizational and management structure (management potential and financial potential);

- development of corporate culture.

There is a great pool of research papers presenting the assessment methodology and comparative analysis of the innovative potential of the universities. The authors identify two major groups of indicators that affect the innovative potential of the university. The first group includes the indicators defining the research and innovation infrastructure of the university (research institutes and laboratories, design offices, pilot production, funds supporting scientific and innovation activities, technology parks, innovation and technology centres, business incubators, small innovative enterprises, marketing services). The second group consists of indicators determining the innovative activity of the university (the implementation of innovative products, the retraining of faculty members, the number of firms-customers of the techno park, the number of new technologies).

Quite obvious is that the new roles of universities demand new management. The traditional management model that has been used for a long period has proven itself well in the context of weak industry competition, the main features of which are stability and sustainability. The positive qualities of the traditional model of management of higher education institutions include collegiality, scholarship, and high level of professionalism. At the same time, in conditions of changing environment, of severe competition between one-profile (pedagogical, humanitarian) and regional high schools, of high intensity of economic, political, and social processes in the society, of reducing the number of university entrants, the traditional methods of management do not allow withstanding the speed of change, and become an obstacle to the implementation of many innovations. For efficient functioning in modern conditions, higher education institutions need to change the traditional model and introduce a new effective management mechanism, training of professional leaders, etc. At the same time, the managers of modern universities should be able to consider and swing with the global innovation environment and current megatrends. 
The dilemma of transforming the university model and increasing the efficiency of management in higher education institutions in Ukraine necessitates the synergy with the current European legislation and global trends. The socioeconomic changes that have taken place over the past two decades in Europe and the US have led to significant transformations in the educational and scientific systems of the countries concerned. The determinants of these changes in Europe and, to a lesser extent, in the US are the demographic situation (ageing of the population, diminishing the proportion of youth in society) and shifting the emphasis on the economic activity of traditionally industrialized countries from industrial production to the service sector and the creative economy concept. As a result, of these and other factors, the place and role of higher education and scientific institutions in society are changing. The educational and scientific systems of many countries, as well as Ukraine, are faced with the task of convergence of all vertices of the "knowledge triangle" higher education, research and, economically and socially significant innovations. Surely, we should confirm that the domestic educational and scientific system, despite the presence of serious specific Ukrainian and post-Soviet problems, in general, develops in accordance with the common European tendencies and is solving the same tasks.

Meanwhile, the growth of the degree of integration of education, science, and innovation will work to address the most pressing problems of the education system, among which increase its quality and bring the structure of training to the real needs of the private and public sectors of the national economy. The result of strengthening the relationship between the educational, research, and innovation components of the educational and scientific system will be the training of personnel better suited to work in the conditions of rapid change and high competition, able to take the initiative and take responsibility. All this will contribute to solving the problems of structural reform of the domestic economy, the creation of new knowledge-intensive innovation productions, and the activation of entrepreneurship. Strengthening the integration of higher education, science, and innovative economic activity will also be a significant contribution to solving the problem of overcoming the systemic contradiction between the existence of a powerful scientific complex capable to produce world-class results and the lack of demand for Ukrainian scientists in the domestic economy.

At the same time, the institutional interaction of universities is expanding. The management functions are delegated both to the top (EU, OECD) and to the local level. In the 1990s, changes in the economic and social role of education, according to the development of knowledge-based society, stimulated the separation of university missions and thereby the diversification of the institutional base of universities. The latter contributes to attracting new sources of funding - both public and private. Universities are included in the EU framework program for the development of research and technology (1984), in the Bologna process (1999). Managerial functions, in particular, in education, are transferred to the territorial level (UK, Italy); decentralized institutions gain more autonomy (Germany); regions are included in the process of forming the national budget of the educational sector (France) (Lane \& Johnstone, 2013; Cole, 2010; Scott, 2009).

Every year universities are becoming the fundamental part of regional economies, public-private partnerships, and supranational systems of socio-economic collaboration. There is a significant university sector, which has joint research centres with scientific entities, for which separate state funding is allocated (France), scientific clusters are developing with the universities participation (Germany) (Paradeise, Reale, Bleiklie, \& Ferlie, 2009). As a result, universities are actively involved in many regional, national and international networks. Heterogeneous education management networks are formed, which influence its development along with the state. The pluralistic form of education management like in Norway, Sweden, Germany, the Netherlands is complemented by its democratization: university councils include external agents who adopt a budget, set priorities, and develop long-term strategies. Considerable attention is focused on the universities' culture management, the development of academic integrity, decentralization, cancellation of obsolete forms of state control.

Literature review shows that various indicators and methods have been applied to measure the 
relationship in question - the strategy of transition to the University 3.0 and University 4.0 model (Lane \& Johnstone, 2013; Lapteva \& Efimov, 2016; FICCI, 2017). However, the following main components can be distinguished:

1) socio-academic - the transformation of the university structure; changes in the academic environment, the educational process and teaching activities; advanced scientific and educational development;

2) research and innovation - the formation of centres of research and technological excellence, the development of open innovation, the implementation of the concept of "university in the centre of the innovation-business ecosystem;"

3) economic - flexible response to labor market (dual education, stakeholders' involvement into education process), focuses on the principles of digital and network economy, management of intellectual property, economically promising elements of corporate and multi-campus universities models.

It should be added that the innovative process in universities, the development of new technologies and their application in practice is not a problem of education or business. Nowadays, this solution became a huge threat to society being, as technology advances contribute to the increase of labor productivity, replacement of job positions by robots and automatic machines (Industry 4.0 progress), which can further exacerbate social inequality (Kharlamova et al., 2018).

Modern universities follow the path of forming the ecosystems that create spaces for experimentally oriented approaches to ventures, focusing on innovation. Entrepreneurial universities are emerging along this path, as university ecosystems facilitate the organization of interdisciplinary hubs linking $\mathrm{R} \& \mathrm{D}$, science and technology, academic and business partnerships. Thus, the mission of universities is expanding - along with education and research, their tasks are socio-economic initiatives that transform the society. The entrepreneurial university promotes the development of a harmonious connection between research and academic entrepreneurship, and its ecosystem can increase the resources of scientific discovery with commercial potential so that it becomes a viable business (Curley \& Formica, 2013).

An innovative and entrepreneurial university should anticipate and track financially and socially significant innovations in the development of science and technology in order to flexibly change and diversify the areas of business activity, that is, to be in a state of dynamic self-renewal. The most important feature of such a university is the expansion of students' competencies (hard and soft skills) and their inclusion in different activities of socio-economic spheres. In the early 2000s, universities began new spin in playing the leading role in the commercial development of scientific knowledge (Thursby \& Kemp, 2002). As a result, the interaction between industry and universities helps to translate scientific discoveries into innovative products and to commercialize in the framework of suitable business models. Mature entrepreneurial universities simultaneously carry out the research, educational and commercial activities that stimulate each other (Etzkowitz, 2008; Etzkowitz \& Leydesdorff, 2000). In complex, University 3.0 (University 4.0) not only supplies personnel or research products. To a much greater extent, its role is to educate innovative-type specialists who are competent to move from research to development with their subsequent commercialization.

A characteristic feature of modern cultural and national reform development in Ukraine is the transformation of management in higher education sphere. The necessity of developing a new management paradigm, the priority directions in the management of higher education institutions is determined by the Laws of Ukraine "On Higher Education" (2014), "On Education” (2017), the National Strategy for the Development of Education in Ukraine for the period up to 2021. However, the role of the innovative and entrepreneurial university with its new system of management and mostly financial management and enterprising freedom is still in the infant state. The legislative base in Ukraine still lacks singling out such characteristic features of a business university as the establishment on its basis of an authoritative scientific centre that: 
- creates the updated scientific and educational products with the rapid passage of the stage of commercialization and entry into the national and global market (R\&D);

- attracts new sources of funding as an addition to the traditional ones (fundraising and crowdfunding).

The additional financing appears in the process of close cooperation with local authorities from the implementation of educational, advisory, or research services for private enterprises, and the receipt of income from own shares of the authorized capital of enterprises.

So-called project-oriented university supposed to become an economic corporation that produces knowledge. Individual faculties and its departments have the opportunity to test their market competitiveness and receive the benefits that are mainly for the university development. In this context, the entrepreneurial university is embarking on a new mission - providing knowledge, support and conditions for graduates and teachers to enter the national and global market with their start-ups and innovative companies.

\section{AIM, HYPOTHESES AND METHODS}

The purpose of the work is to model and analyze the innovative environment and its impact factors for the development of the innovative and entrepreneurial university in Ukraine based on the theoretical and methodological principles and practical aspects of the formation and implementation of the concept of the innovation and entrepreneurial model of a modern university.

Quite obvious is that before the modelling approach, we should issue some hypotheses to be tested. The first hypothesis of the study supposes that the current reform of higher education in Ukraine does not sufficiently take into the account the existing possibilities of entrepreneurial activity of universities in realizing the innovative potential of the national economy. The second hypothesis says that the institutional and socio-economic features of each country determine the specific set of models for the functioning of universities. The third hypothesis assumes that the main constituents of modern universities are innovations, entrepreneurship, management, competition, market, leadership, finance, risks. However, the testing of these hypothesis challenges the lack of statistics to follow the main trends, especially in Ukraine. So, the main analyses of the paper will be concentrated on the macro trends in the field under consideration.

To achieve the goal of the work, methods of analysis and synthesis were used to disclose the concept of innovative-entrepreneurial universities; comparative analysis - to study the factors influencing university sector development; quantitative analysis (panel regression) - to calculate the impact of different factors on the level of GII; concretization and analogy - to formulate conclusions and suggestions on improving the level of education by innovative-entrepreneurial universities development.

\section{RESULTS}

The growth of innovations in the economy is often associated with the significant investment in education, an increase in the number of people with higher education, the introduction of new technologies in education. We attempt to analyze how the global economy has responded to the challenges of the past. Hence, Figure 2 shows the dynamics of government spending on education as a percentage of GDP, as well as a percentage of the total budget.

As we can observe, there is an increasing trend in the cost of education for government worldwide. Over the past 15 years, the share of GDP for education in the world has increased from 4.2 to $4.8 \%$. At the same time, due to the competitive reduction of taxes, the optimization of state budgets, budget expenditures on education increased quite insignificantly (from 13.3 to $13.9 \%$ ).

However, such an increase in funding did not allow a significant increase in the Global Innovation Index. Table 1 provides the information on changes in this index over the past six years for the countries-leaders and Ukraine. One should note that there has not been a significant increase in 
2000200120022003200420052006200720082009201020112012201320142015

Government expenditure on education, total (\% of government expenditure)

Figure 2. Government expenditure on education, 2000-2015

the Index in most of the leading countries, or even its fall has been marked. Canada has dropped from 57.6 to 53, Hong Kong - from 59.43 to 54.60, Ireland - from 57.91 to 57.20 , and the UK - from 61.25 to 60.10 . At the same time, the poorest countries were able to improve their indices. This can be explained by the equalization processes in the world, as well as low base for the comparison in poorer countries, especially in Africa.

Table 1. Global Innovation Index

Source: Built by the authors based on Global Innovation Index (2019)

\begin{tabular}{|c|c|c|c|c|c|c|}
\hline Country & 2013 & 2014 & 2015 & 2016 & 2017 & 2018 \\
\hline Canada & 57.60 & 56.13 & 55.70 & 54.71 & 53.65 & 53.00 \\
\hline Denmark & 58.34 & 57.52 & 57.70 & 58.45 & 58.70 & 58.40 \\
\hline Finland & 59.51 & 60.67 & 60.00 & 59.90 & 58.49 & 59.60 \\
\hline Germany & 55.83 & 56.02 & 57.10 & 57.94 & 58.39 & 58.00 \\
\hline Hong Kong & 59.43 & 56.82 & 57.20 & 55.69 & 53.88 & 54.60 \\
\hline Ireland & 57.91 & 56.67 & 59.10 & 59.03 & 58.13 & 57.20 \\
\hline Netherlands & 61.14 & 60.59 & 61.60 & 58.29 & 63.36 & 63.30 \\
\hline Singapore & 59.41 & 59.24 & 59.40 & 59.16 & 58.69 & 59.80 \\
\hline Sweden & 61.36 & 62.29 & 62.40 & 63.57 & 63.82 & 63.10 \\
\hline Switzerland & 66.59 & 64.78 & 68.30 & 66.28 & 67.69 & 68.40 \\
\hline Ukraine & 35.78 & 36.26 & 36.50 & 35.72 & 37.62 & 38.50 \\
\hline $\begin{array}{l}\text { United } \\
\text { Kingdom }\end{array}$ & 61.25 & 62.37 & 62.40 & 61.93 & 60.89 & 60.10 \\
\hline $\begin{array}{l}\text { United States } \\
\text { of America }\end{array}$ & 60.31 & 60.09 & 60.10 & 61.40 & 61.40 & 59.80 \\
\hline
\end{tabular}

Thus, we can consider that in general, the innovation development index varies around the same trajectory as the total cost of education. Considering this, we try to adopt for testing the following hypotheses:

$H_{0}: \quad$ There is a dependence between the Global Innovation Index and the factors of the funding for education in the country.
$H_{1}$ : The dependence between the Global Innovation Index and the factors of the amount of funding for education in the country is not traceable.

To test the hypotheses, we use the countries listed in Table 1, except for Singapore and Hong Kong, for which there are no data on education expenditures. Taking in the account that some data on the World Bank site are missing, the objective test tool is an unbalanced panel regression, where the dependent variable is the innovation development index over the past 6 years, and the independent variable is lag of education expenditures as a share of the budget:

$$
y_{i t}=\beta_{0}+\beta_{1} x_{i t-k}+\varepsilon_{i t},
$$

where $y_{i t}$ - the Global Innovation Index of the $i$-th state in the period $t, x_{i t}$ - the share of education expenditures in the total budget of the $i$-th country in the period $t-k, k-$ the beginning period of the impact of expenditures in years, $\beta_{0}, \beta_{1}$ - coefficients of the model, $\varepsilon_{i t}$ - residuals, model errors.

Results of the modelling are presented in Table 2.

The evaluation of the model demonstrated that, initially, the Innovation development index has a rather high level of dependence on itself, almost $97 \%$ of its value is determined by its previous characteristics. This means that no country has a chance to make a revolutionary breakthrough in the value of this index. At the same time, its value can be influenced by the education expendi- 
Table 2. Model results - 1

Source: Authors' assessments.

\begin{tabular}{|c|c|c|c|c|}
\hline \multicolumn{5}{|c|}{ Dependent variable: INDINN } \\
\hline \multicolumn{5}{|c|}{ Method: panel least squares } \\
\hline \multicolumn{5}{|c|}{ Date: 04/26/19 Time: 10:02 } \\
\hline \multicolumn{5}{|c|}{ Sample (adjusted): 2014-2018 } \\
\hline \multicolumn{5}{|l|}{ Periods included: 5} \\
\hline \multicolumn{5}{|c|}{ Cross-sections included: 11} \\
\hline \multicolumn{5}{|c|}{ Total panel (unbalanced) observations: 47} \\
\hline Variable & Coefficient & Std. error & t-statistic & Prob. \\
\hline C & 2.002425 & 1.835204 & 1.091119 & 0.2812 \\
\hline INDINN(-1) & 0.968254 & 0.030975 & 31.25938 & 0.0000 \\
\hline$D\left(G O V \_B U D(-4)\right)$ & 0.375274 & 0.195456 & 1.919991 & 0.0614 \\
\hline$R$-squared & 0.957335 & \multicolumn{2}{|c|}{ Mean dependent var } & 59.06426 \\
\hline Adjusted $R$-squared & 0.955396 & \multicolumn{2}{|c|}{ S.D. dependent var } & 6.556433 \\
\hline S.E. of regression & 1.384699 & \multicolumn{2}{|c|}{ Akaike info criterion } & 3.550544 \\
\hline Sum squared resid & 84.36520 & \multicolumn{2}{|c|}{ Schwarz criterion } & 3.668639 \\
\hline Log likelihood & -80.43778 & \multicolumn{2}{|c|}{ Hannan-Quinn crit. } & 3.594984 \\
\hline F-statistic & 493.6469 & \multicolumn{2}{|c|}{ Durbin-Watson stat } & 3.351304 \\
\hline $\operatorname{Prob}(F$-statistic) & 0.000000 & \multicolumn{2}{|c|}{-} & - \\
\hline
\end{tabular}

tures. However, the results of this effect begin to be determined only 4 years after the corresponding changes, which in general, corresponds to the period of training in the HEI.

Thus, the growth of government expenditures by $1 \%$ leads to an increase in the Global Innovation Index by 0.375 in 4 years. Because almost all countries have expenditures at a relatively close level (Figure 3), the magnitude of the growth of this Index is very limited. For example, in the countries under review, the education funding ranged from 9.28 to $16.01 \%$ of the total budget. Since the average value is $13.03 \%$ of the budget, even with the maximum increase in expenditures (up to $16 \%$ ), it is possible to improve the Global Innovation Index by only 1 point in just 4 years. Given the fact that the political cycle is usually $4-5$ years, it will not be beneficial for the political parties to make appropriate changes to the financing of the education, since they will not be able to boast of results during their cadence.

However, the proposed analysis cannot be decisive for the development of economic policy. Since the state can spend much money, but inefficiently. It is necessary to analyze how effectively the financing of educational programs is carried out. Obviously, at present, the indicators that are recognized by the business can be understood as efficient, that is funds the real companies are willing to pay. Thus, we cannot consider for the assessment such indicators, which are achieved through the budget financing. Therefore, it is impossible to use, for example, the number of universities, the number of students, the number of quotes, or similar param-

Source: Authors' assessments.

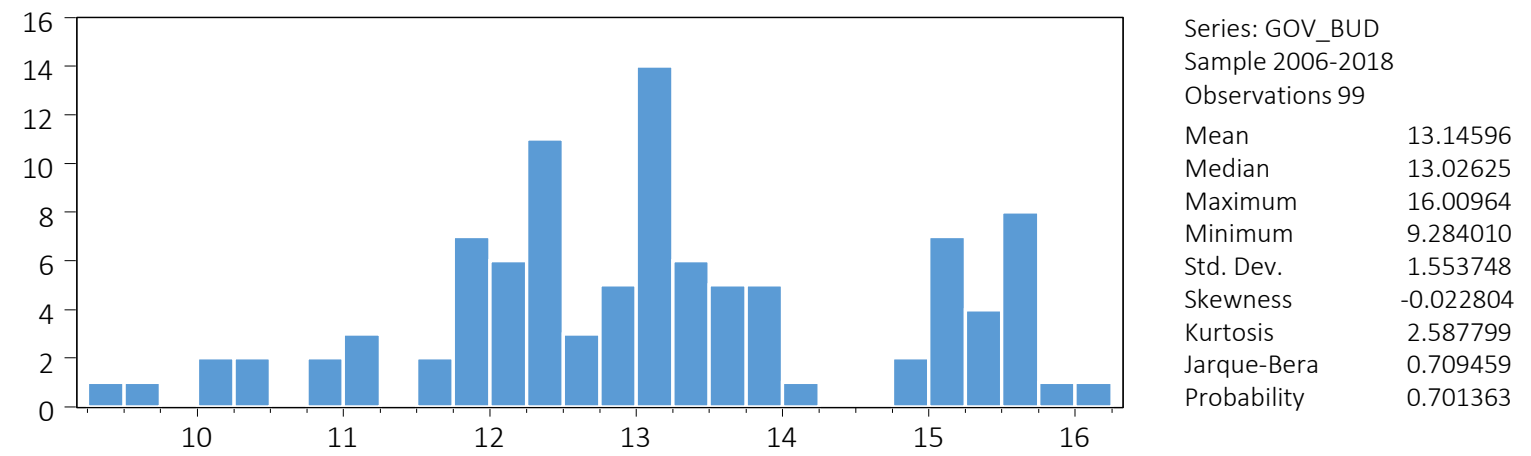

Figure 3. Histogram of the distribution of the share of education costs to the general budget of the countries 
eters. In our opinion, the active part of the pop- $H_{0}$ ulation working in the field of new technologies (Human Resources in Science and Technology - HRST) can be a bright indicator of efficiency. Unfortunately, such statistics are available only for European countries, so our analysis is applicable just for some European countries (Table 3).

Our intention is to consider if there is a relationship between the indicator and the index of innovative economic development considered in Table 2. Thus, our hypotheses will look like:
An increase in the share of the population working in the technological industries increases the Global Innovation Index of the country.

$H_{1}: \quad$ An increase in the share of the population working in the technological industries does not affect the Global Innovation Index of the country.

Applying a similar econometric apparatus for analysis, we use a balanced panel regression since there are no missing data:

Table 3. Human Resources in Science and Technology (HRST), \% of active population

Source: Built by the authors based on Eurostat.

\begin{tabular}{|c|c|c|c|c|c|c|c|c|c|c|c|c|}
\hline Geo & 2007 & 2008 & 2009 & 2010 & 2011 & 2012 & 2013 & 2014 & 2015 & 2016 & 2017 & 2018 \\
\hline EU (28 countries) & 39.0 & 39.5 & 40.1 & 40.8 & 42.3 & 43.1 & 43.8 & 44.5 & 45.2 & 46.0 & 46.6 & 47.5 \\
\hline Euro area (19 countries) & 40.0 & 40.5 & 40.9 & 41.4 & 42.3 & 43.1 & 43.7 & 44.3 & 45.0 & 45.6 & 46.3 & 47.1 \\
\hline Belgium & 46.7 & 47.0 & 48.2 & 49.3 & 49.6 & 50.3 & 49.6 & 51.1 & 50.5 & 51.1 & 54.3 & 54.4 \\
\hline Bulgaria & 30.8 & 31.4 & 31.8 & 32.1 & 32.7 & 32.8 & 34.0 & 35.4 & 36.3 & 36.8 & 36.5 & 36.8 \\
\hline Czech Republic & 36.0 & 37.1 & 37.9 & 37.8 & 35.9 & 36.6 & 37.2 & 38.1 & 38.1 & 38.7 & 39.6 & 39.9 \\
\hline Denmark & 47.5 & 49.4 & 50.0 & 51.0 & 51.5 & 52.9 & 53.5 & 54.0 & 54.5 & 54.8 & 56.4 & 57.1 \\
\hline Germany & 42.9 & 44.0 & 44.9 & 45.7 & 44.8 & 46.4 & 46.8 & 47.0 & 47.7 & 48.4 & 48.7 & 49.3 \\
\hline Estonia & 44.4 & 44.4 & 45.9 & 45.2 & 47.3 & 49.2 & 48.9 & 48.9 & 49.3 & 49.1 & 50.3 & 52.0 \\
\hline Ireland & 43.4 & 44.5 & 46.2 & 47.5 & 50.3 & 51.9 & 52.8 & 53.1 & 54.2 & 54.9 & 56.6 & 57.2 \\
\hline Greece & 31.4 & 31.9 & 32.0 & 32.5 & 33.7 & 34.3 & 35.1 & 35.4 & 36.1 & 37.4 & 38.5 & 39.2 \\
\hline Spain & 39.4 & 38.9 & 38.8 & 39.6 & 40.1 & 40.4 & 41.2 & 42.2 & 42.7 & 43.4 & 44.3 & 45.1 \\
\hline France & 41.6 & 42.6 & 43.5 & 43.8 & 47.4 & 48.1 & 48.9 & 49.1 & 49.9 & 50.5 & 50.8 & 52.1 \\
\hline Croatia & 28.3 & 29.0 & 30.3 & 31.6 & 29.8 & 31.5 & 34.5 & 35.1 & 36.2 & 37.4 & 38.2 & 40.0 \\
\hline Italy & 35.6 & 35.4 & 34.4 & 34.0 & 34.6 & 34.7 & 34.8 & 35 & 35.5 & 35.7 & 36.3 & 37.0 \\
\hline Cyprus & 42.5 & 43.7 & 43.0 & 44.0 & 47.1 & 48.5 & 47.9 & 48.8 & 49.3 & 50.6 & 50.9 & 52.0 \\
\hline Latvia & 36.9 & 39.4 & 38.7 & 38 & 38.2 & 40.1 & 41.2 & 40.7 & 42.4 & 43.3 & 44.4 & 44.4 \\
\hline Lithuania & 39.9 & 42.3 & 41.7 & 42.7 & 43.6 & 43.9 & 45.6 & 46.5 & 48.2 & 49.1 & 49.4 & 50.5 \\
\hline Luxembourg & 43.3 & 45.5 & 55.5 & 56.2 & 57.3 & 58.9 & 61.1 & 64.5 & 58.8 & 59.6 & 57.6 & 61.2 \\
\hline Hungary & 31.8 & 33.3 & 33.3 & 33.0 & 34.6 & 35.6 & 36.0 & 36.3 & 36.7 & 36.3 & 36.5 & 37.3 \\
\hline Malta & 31.8 & 32.2 & 32.7 & 32.6 & 35.3 & 37.6 & 39.0 & 39.5 & 40.2 & 40.3 & 42.8 & 45.5 \\
\hline Netherlands & 48.3 & 49.0 & 49.6 & 50.9 & 51.8 & 52.1 & 52.7 & 52.8 & 53.6 & 54.6 & 55.3 & 56.9 \\
\hline Austria & 37.5 & 37.7 & 38.9 & 39.1 & 40.4 & 41.7 & 43.0 & 48.3 & 48.6 & 49.1 & 50.1 & 50.4 \\
\hline Poland & 32.5 & 33.4 & 34.9 & 35.9 & 36.6 & 37.7 & 39.0 & 40.4 & 41.6 & 42.8 & 44.0 & 45.2 \\
\hline Portugal & 22.0 & 23.0 & 23.5 & 23.9 & 26.9 & 28.7 & 30.0 & 33.0 & 34.8 & 36.2 & 36.4 & 37.5 \\
\hline Romania & 23.0 & 23.8 & 24.1 & 24.0 & 25.4 & 25.5 & 25.1 & 25.6 & 27.0 & 27.6 & 27.7 & 27.9 \\
\hline Slovenia & 38.9 & 40.1 & 40.6 & 40.8 & 42.4 & 42.8 & 43.5 & 43.7 & 45.1 & 46.5 & 47.8 & 47.4 \\
\hline Slovakia & 31.8 & 32.0 & 32.0 & 33.5 & 33.9 & 32.5 & 32.5 & 32.9 & 33.5 & 34.2 & 35.2 & 36.9 \\
\hline Finland & 49.4 & 49.8 & 50.4 & 51.4 & 52.6 & 53.6 & 54.6 & 55.6 & 56.5 & 56.9 & 57.7 & 58.4 \\
\hline Sweden & 48.7 & 49.3 & 49.7 & 50.3 & 51.7 & 52.6 & 53.8 & 55.1 & 56.2 & 57.9 & 58.6 & 59.9 \\
\hline United Kingdom & 43.5 & 43.7 & 44.6 & 46.3 & 52.4 & 53.3 & 54.1 & 54.6 & 55.5 & 56.9 & 57.1 & 57.6 \\
\hline Iceland & 46.4 & 48.2 & 50.0 & 49.7 & 51.3 & 51.4 & 53.0 & 54.1 & 55.4 & 57.2 & 57.7 & 59.0 \\
\hline Norway & 49.7 & 50.5 & 50.8 & 51.4 & 54.6 & 55.4 & 56.3 & 58.7 & 59.7 & 59.3 & 59.1 & 59.2 \\
\hline Switzerland & 51.6 & 53.4 & 54.4 & 52.4 & 53.4 & 54.3 & 55.8 & 56.7 & 57.4 & 58.7 & 59.9 & 60.8 \\
\hline Montenegro & - & - & - & - & 35.6 & 35.9 & 37.5 & 38.8 & 37.1 & 38.1 & 37.2 & 36.8 \\
\hline North Macedonia & 23.1 & 21.8 & 23.4 & 24.1 & 27.0 & 27.6 & 26.4 & 26.8 & 28.6 & 30.9 & 31.4 & 31.7 \\
\hline Serbia & - & - & - & 30.6 & 21.3 & 22.4 & 30.9 & 32.7 & 33.4 & 33.6 & 34.4 & 35.2 \\
\hline Turkey & 19.9 & 20.5 & 20.7 & 20.9 & 21.7 & 23.1 & 23.8 & 24.7 & 26.3 & 27.5 & 28.1 & 28.8 \\
\hline
\end{tabular}


Table 4. Model results - 2

Source: Authors' assessments.

Dependent variable: IndInn

Method: panel least squares

Date: 04/26/19 Time: 14:17

Sample (adjusted): 2013-2018

Periods included: 6

Cross-sections included: 26

Total panel (balanced) observations: 156

\begin{tabular}{|c|c|c|c|c|}
\hline Variable & Coefficient & Std. error & $t$-statistic & Prob. \\
\hline $\mathrm{C}$ & 16.61636 & 1.801684 & 9.222685 & 0.0000 \\
\hline HRST(-1) & 0.753194 & 0.039088 & 19.26909 & 0.0000 \\
\hline$R$-squared & 0.706833 & \multicolumn{2}{|c|}{ Mean dependent var } & 50.64917 \\
\hline Adjusted $R$-squared & 0.704929 & \multicolumn{2}{|c|}{ S.D. dependent var } & 8.182839 \\
\hline S.E. of regression & 4.444952 & \multicolumn{2}{|c|}{ Akaike info criterion } & 5.834153 \\
\hline Sum squared resid & 3042.670 & \multicolumn{2}{|c|}{ Schwarz criterion } & 5.873253 \\
\hline Log likelihood & -453.0639 & \multicolumn{2}{|c|}{ Hannan-Quinn criter. } & 5.850034 \\
\hline F-statistic & 371.2978 & \multicolumn{2}{|c|}{ Durbin-Watson stat } & 0.121781 \\
\hline Prob (F-statistic) & 0.000000 & \multicolumn{2}{|c|}{-} & - \\
\hline
\end{tabular}

$$
y_{i t}=\beta_{0}+\beta_{1} x_{i t-1}+\varepsilon_{i t} \text {, }
$$

where $y_{i t}$ - Global Innovation Index of $i$-th state in the period $t, x_{i t-1}$ - the share of the population working in the technological industries in the $i$ th state in the period $t-1, \beta_{0}, \beta_{1}$ - model coefficients, $\varepsilon_{i t}$ - errors of the model, residuals.

The results of modelling are presented in Table 4.

It can be seen the every additional $1 \%$ of people working with new technologies increases the level of Global Innovation index by 0.75 each year. The results of this modelling show that only education expenditures are not able to guarantee the innovation growth. The innovation growth is impossible without the business cooperation in the network with the universities. This should take place so that new technologies are actively used in practice.

As to Ukraine, such a task is of paramount importance, since the level of business engagement with universities is at an incredibly low level. In order to illustrate how weak universities in Ukraine influence the innovation development, we consider the dynamics of the number of HEIs and the number of students in Ukraine in comparison with the dynamics of the Global Innovation Index - GII (Figures 4, 5). The growth of the GII in Ukraine is taking place against the backdrop of reducing the number of HEIs and the number of students. This means that the proportion of students who have not gone into an HEI raises the level of innovation in Ukraine through outsourcing, IT work, etc.

Source: Authors' assessment.

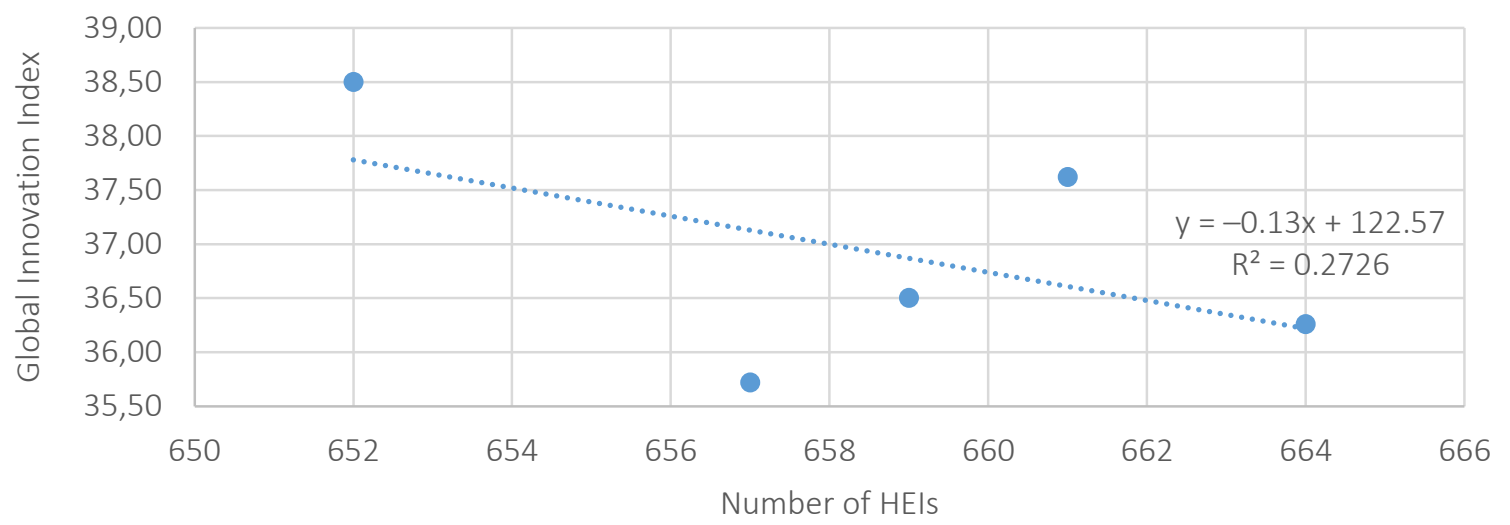

Figure 4. Dependence between the number of HEls and the GII in Ukraine 
Source: Authors' assessment.

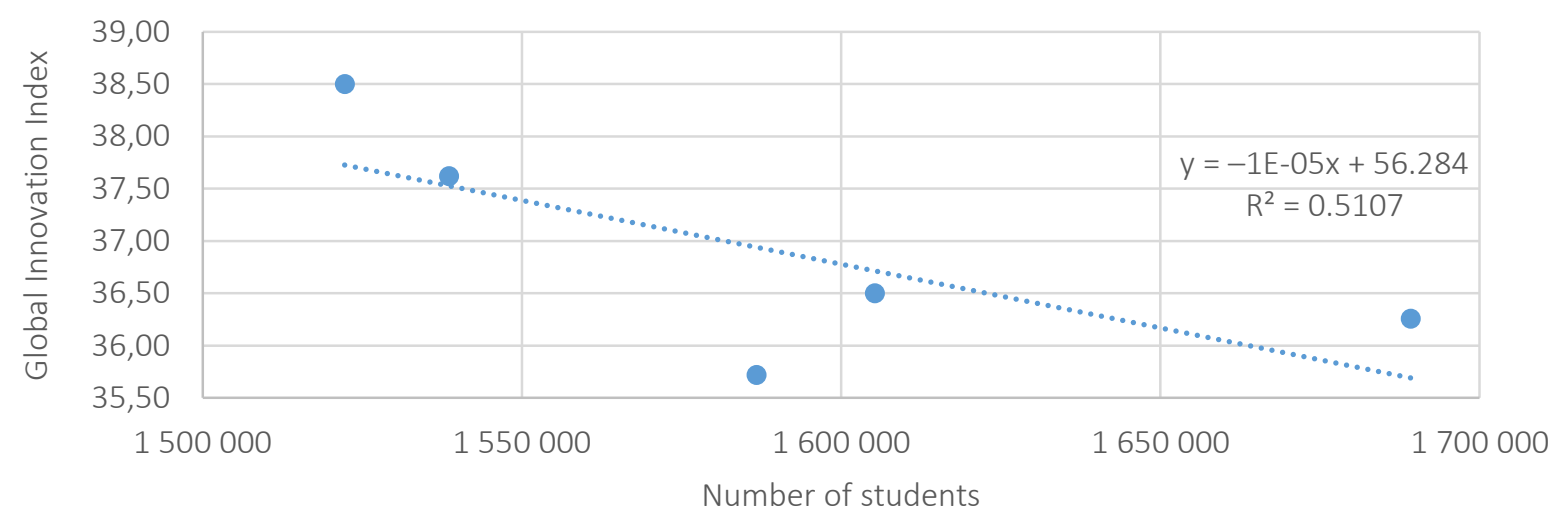

Figure 5. Dependence between the number of students and the GII in Ukraine

Thus, we can conclude that the Ukrainian environment does not contribute to the development of innovation and entrepreneurial universities, and, in fact, the education expenditures are ineffective. This means that Ukraine needs a completely different approach to higher education development than most of the EU countries.

\section{DISCUSSION}

The concept of developing a modern university model in Ukraine enables to stimulate the innovation activity in the national economy through the formation of entrepreneurial principles and synergies in the chain of power-business-education and science.

The theoretical and methodological basis of the article is the scientific and practical comprehension of the achievements of foreign and domestic scientists in the field of the "academic capitalism" theory, in particular, the phenomenon of university entrepreneurship and its role in the formation of innovation-investment economy in the context of increasing the importance of commercially attractive knowledge, the need to strengthen the national security and the implementation of the strategy of the European vector for Ukraine. To solve the tasks and to ensure the conceptual integrity, the paper implemented a number of general scientific and special research methods and techniques, in particular, methods of historicism, synthesis, theoretical and abstract-logical generalization, benchmarking, as well as statistical analy- sis, economic and mathematical modelling. The implementation of our scientific research was based on interdisciplinary and problem-oriented-purpose approaches, the formation and implementation of the concept of the formation of an innovation and entrepreneurial model of a modern university in Ukraine.

The analysis of foreign and domestic experience shows that solving the task of building a modern competitive economy and the knowledge society requires the optimal use of the latest models of innovative processes. The research innovation universities are an important component of it. Such HEIs, working in close partnership with the state and local self-government and economic actors, are increasingly turning into centres of innovation development, achieving the significant acceleration of the research and development processes implementation in the demand-driven economy of technology, goods, and services.

The simulation results showed that the level of the Ukrainian economy does not yet create the sufficient conditions for the ordering of a scientific product. Therefore, the results of fundamental and applied research should be used by the higher education institution in order to preserve the intellectual potential of the country. This is possible based on the integration of academic science, higher education, and business. To overcome the gap between the academic and university science and business, it is necessary to create the joint educational and scientific centres. In fact, the boundary between the research 
and educational work, between the teacher-scientist and entrepreneur-innovator will disappear. That is because science will transfer the latest achievements to education, forming its advanced content, and the higher education in- stitution will fill the scientific sphere with future scientists who possess the modern methodology of science, simultaneously testing the scientific products on the market through business models.

\section{CONCLUSION}

Given the need to develop an innovative economy, as well as considering both the positive and the negative aspects of the experience to develop a system of research universities in Ukraine, the development of innovative research universities requires formation of modern educational and research centres, which involve in their work both the teachers, students and postgraduate students of universities and specialists of relevant research institutions, ensuring the conditions for maximum use of the existing research and educational infrastructure for their work. This in turn demands formation of modern educational and research centres, which involve in their work both the teachers, students and postgraduate students of universities and specialists of relevant research institutions, ensuring the conditions for maximum use of the existing research and educational infrastructure for their work.

In this paper it was shown that currently countries slowly increase their expenditures on education, but it doesn't lead to clear increase in innovations. However, we discovered a dependence between the Global Innovation Index and the factors of the funding for education in the country. Share of education expenditures in country can lead to increase of state's innovation index only in four years, which is similar to one education cycle in higher education. At the same time universities are not the only ones, who can increase innovation level in the country. Our investigation showed that increase in the share of the population working in the technological industries increases the Global Innovation Index of the country. It means that country, which goals innovation leadership, has a choice. From the one hand, it can attract technological industries giving salaries exceeding market level. Such policy will bring new people from abroad but will be quite costly. From the other hand, it can invest more in technological development of universities, for example, to form modern educational and research centres, which involve in their work both the teachers, students and postgraduate students of universities and specialists of relevant research institutions, ensuring the conditions for maximum use of the existing research and educational infrastructure for their work. The results will be more stable, but one should wait four time more to get them.

As usually, the best strategy lies between proposed solutions. Government must intensify the dialogue between higher education institution, scientific institutions, business representatives, and state bodies on the increase of the innovation activities efficiency, expand the autonomy of universities and research institutions both in the implementation of the educational process and research and in the field of economic activity, giving the possibility to combine the best practices from scientific and business activity. It creates stimulus for the maximum rapid commercialization of the results of perspective R\&D, dissimilating new technologies must faster.

A very important question is to understand the necessary amount of such universities in the country. We have shown a case from Ukraine, where there are hundreds of universities, which can't have sufficient financing for any research or business activity. It means that most of funding spend non-efficiently, dissimulating technological progress. It leads to the conclusion that Ukrainian government should change budgeting policy in educational sphere as soon as possible to prevent a further technological and innovative lag. Such change should lead to paradigm shift, where the focus in university activity should be made on quality of knowledge, their applicability and possibility to commercialize it. This will start a spiral increase in innovative process and number of employers in innovation sphere. 


\section{ACKNOWLEDGEMENT}

Paper is prepared in the framework of scientific faculty research of Taras Shevchenko National University of Kyiv "Innovative and entrepreneurial models of modern universities: world trends, main risks and new opportunities for Ukraine," 19BF040-01.

\section{REFERENCES}

1. Cole, J. R. (2010). The great American university: its rise to preeminence, its indispensablenation role, why it must be protected. New York: Public Affairs. Retrieved from https://www.amazon.com/ Great-American-UniversityPreeminence-Indispensable/ $\mathrm{dp} / 1610390970$

2. Curley, M., \& Formica, P. (2013). The experimentalnature of new venture creation: Capitalizing on open innovation 2.0. New York: Springer. Retrieved from https:// books.google.com.ua

3. Etzkowitz, H. (2008). The Triple Helix: university-industrygovernment: innovation in action. London: Routledge.

4. Etzkowitz, H., \& Leydesdorff, L. (2000). The dynamics of innovation: from national systems and "Mode 2" to a Triple Helix of university-industry-government relations. Research Policy, 29(2), 109123. http://dx.doi.org/10.1016/ S0048-7333(99)00055-4

5. European Commission (2003). Green Paper. Entrepreneurship in Europe. Retrieved from https:// ec.europa.eu/invest-in-research/ pdf/download_en/entrepreneurship_europe.pdf

6. European Commission (2006). Economic reforms and competitiveness: key messages from the European Competitiveness Report 2006. Retrieved from http://aei-dev.library.pitt. edu/45435/

7. Eurostat, the Statistical Office of the European Communities (2007). European business - Facts and figures (448 p.). Retrieved from https://ec.europa.eu/eurostat/web/products-statisticalbooks/-/KS-BW-07-001
8. FICCI (2017). Leapfrogging to Education 4.0: Student at the core (80 p.). Retrieved from https:// www.parthenon.ey.com/po/en/ perspectives/leapfrogging-to-education-4-0-student-at-the-core

9. General Accounting Office (GAO) (1980). Bayh-Dole Act. Retrieved from https://www.gao.gov/archive/1998/rc98126.pdf

10. Global Innovation Index (2019). The Global Innovation Index (GII) 2019: Creating Healthy Lives - The Future of Medical Innovation. Retrieved from https://www.globalinnovationindex.org

11. Karpov, A. O. (2017). Sovremennyy universitet kak draivar ekonomicheskogo rosta: modeli i missii [Modern university as an economic growth driver: models \& missions]. Voprosy Ekonomiki, 3, 58-76. (In Russian). http://doi. org/10.32609/0042-8736-20173-58-76

12. Kharlamova, G. O., Stavytskyy, A. V., \& Zarotiadis, G. (2018). The impact of technological changes on income inequality: the EU states case study. Journal of International Studies, 11(2), 76-94. http://dx.doi.org/10.14254/20718330.2018/11-2/6

13. Koziuk, V., Dluhopolskyi, O., Hayda, Y., \& Klapkiv, Y. (2019). Does education quality drive ecological performance? Case of high and low developed countries. Global Journal of Environmental Science and Management, 5(S1), 22-32. https://doi.org/10.22034/ GJESM.2019.05.SI.03

14. Kutsenko, V. I. (2010). Spivpratsia osvity ta nauky u rozbudovi innovatsiinoi ekonomiky [Collaboration of education and science in the development of innovative economy]. Marketynh i menedzh- ment innovatsii-Marketing and innovation management, 2, 100107. (In Ukrainian). Retrieved from http://www.irbis-nbuv.gov. ua/cgi-bin/irbis_nbuv

15. Lane, J. E., \& Johnstone, D. B. (2013). Higher education system 3.0: Harnessing system ness, delivering performance. New York: SUNY Press.

16. Lapteva, A. V., \& Efimov, V. S. (2016). New Generation of Universities. University 4.0. Journal of Siberian Federal University. Humanities \& Social Sciences, 11(9), 2681-2696. Retrieved from http://elib.sfu-kras.ru/handle/2311/29969

17. Lee, R., \& Mason, A. (2010). Fertility, Human Capital, and Economic Growth over the Demographic Transition. European Journal of Population, 26(2), 159-182. Retrieved from https:// link.springer.com/article/10.1007/ s10680-009-9186-X

18. Leutz, W. (2012). Foreign-Born Workers in Long-Term Supportive Services. Public Policy \& Aging Report, 22(2), 1-11. https://doi. org/10.1093/ppar/22.2.17

19. Makrides, G. A. (2019). The Evolution of Education from Education 1.0 to Education 4.0: Is it an evolution or a revolution? Retrieved from https://www.l-cloud. eu/wp-content/uploads/2019/03/ Evolution_of_Education.pdf

20. Molchanova, E. Yu., \& Dluhopolskyi, O. V. (2019). Vid pokolinnia $\mathrm{X}$ do pokolinnia Z: vyklyky dlia osvity ta biznesu [From generation $\mathrm{X}$ to generation $\mathrm{Z}$ : challenges for education and business]. In T. Finikov \& Sukharski (Eds.), Innovatsiinyi universytet i liderstvo: proekt i mikroproekty - III [Innovative university and leadership: 
project and microprojects - III] (pp. 300-315). Warsaw: Wydzial "Artes Liberales” UW. (In Ukrainian).

21. Nour, S. M. (2016). Economic Systems of Innovation in the Arab Region (309 p.). Palgrave Macmillan US. http://dx.doi. org/10.1057/9781137462213

22. Osetskyi, V. L. (2017). Yakisnyi osvitnii protses $v$ umovakh universytetskoi avtonomii [Qualitative educational process in the conditions of university autonomy]. Internatsionalizatsiia osvity i nauky: natsionalni osoblyvosti ta svitovi tendetsii: kolektyvna monohrafiia [Intenationalization of education and science: national peculiarities and global tendencies: joint monograph]. (In Ukrainian). Kyiv.

23. Osetskyi, V. L. (2018). Strategic priorities of innovative development of institutional architecture of economy of Ukraine and Georgia. Strategic priorities for Developing Ukraine and Georgia: Innovation and Partnership (308 p.). Batumi. Retrieved from http:// ir.kneu.edu.ua/handle/2010/25194

24. Paradeise, C., Reale, E., Bleiklie, I., \& Ferlie, E. (2009). University governance. Western European
Comparative Perspectives. Netherlands: Springer. Retrieved from https://www.springer.com/gp/ book/9781402086373

25. Rai, S. M., Brown, B. D., \& Ruwanpura, K. N. (2019). SDG 8: Decent work and economic growth - a gendered analysis. World Development, 113, 368-380. https://doi.org/10.1016/j.worlddev.2018.09.006

26. Reichert, S., \& Tauch, Ch. (2003). Trends 2003: Progress towards the European Higher Education Area. Retrieved from https://eua.eu/ downloads/publications

27. Scott, R. (2009). Innovative strategy in the Great Britain. Foresight-Russia, 3(4), 16-21. http://dx.doi.org/10.17323/1995459x.2007.1.74.79

28. Shevchenko, V. V. (2019). The reform of the higher education of Ukraine in the conditions of the military political crisis. International Journal of Educational Development, 65, 237-253. http://dx.doi.org/10.1016/j. ijedudev.2018.08.009

29. Sotula, O., \& Denysenko, V. (2019). Application of fuzzy logic approach for the determination of the integral index of the implicit impact of the higher education system on regional development (on the example of Ukraine). The 8th International Conference on Monitoring, Modeling \& Management of Emergent Economy (M3E2 2019), 65.

Retrieved from https://www.shsconferences.org/articles/shsconf/ abs/2019/06

30. Stavytskyy, A. V. (2018). Challenges for Higher Education: The Case of Ukraine. In Sustainable Futures for Higher Education (pp. 109-113). Retrieved from https:// link.springer.com/chapter /10.1007/978-3-319-96035-7_11

31. Stillman, D. (2018). Lyudi Z [People Z]. Harvard Business Review Rossiya - Harvard Business Review Russia. (In Russian). Retrieved from https://hbr-russia. $\mathrm{ru} /$ management/upravleniepersonalom

32. Thursby, J. G., \& Kemp, S. (2002). Growth and Productive Efficiency of University Intellectual Property Licensing. Research Policy, 31(1), 109-124. https://doi.org/10.1016/ S0048-7333(00)00160-8 